УДК 821.163.41.09:398 Јакобсон, Р. https://doi.org/10.18485/msc50.2019.1.ch14

\title{
Светозар Петровић
}

\section{ЈАКОБСОНОВ ОПИС СРПСКОХРВАТСКОГ ЕПСКОГ ДЕСЕТЕРЦА}

Класичан Јакобсонов опис српскохрватског епског десетерца, први пут систематски изложен прије више од четрдесет година ${ }^{1}$, може да послужи као врло добар примјер једне посебне врсте интереса што га је тај стих, донекле и српскохрватски стих уопће, у науци побуђивао. Проучавању српскохрватског стиха, напосе епског десетерца, посљедњи циљ није, наиме, увијек био да се баш он као посебна појава схвати и опише. Више пута, од времена пионира компаративне метрике у 19. вијеку преко Ф. Зарана и Н. Трубецкоја до сувремених теоретичара усмене епске креације, циљ је био много далекосежнији - окушавање неког новог поступка у описивању стиха, или доказивање неке опће теорије стиха или епске поезије или језика - а епски десетерац, настао у језику размјерно сложеног прозодијског система, показивао се за то подесном грађом.

Јакобсонов опис српскохрватског епског десетерца можда је најкарактеристичније и најзначајније такво искушавање једне методологије на грађи српскохрватског стиха. О његовој изворној даљој сврси каже понешто околност да је то био реферат на међународном конгресу фонетичара у Амстердаму 1932, свега четири године послије првог колективног наступа прашке школе на међународној научној сцени, а пред аудиторијем који прашким фонолозима није био изузетно склон. И овај пут неколико научника из Прага наступа понешто програматски, са рефератима који су међусобно координирани. Нису то све додуше људи прашке школе (уз Јакобсона о српскохрватској епици говоре и Г. Геземан и Г. Бекинг), али наступом доминирају реферати Јакобсона и Мукаржовског (Мукаржовски излаже своје познато гледиште о интонацији као фактору пјесничког ритма). Како већ бива, изазовни наступ није на конгресу изазвао на ријечи дискусије.

1 „Über den Versbau der serbokroatischen Volksepen”, Archives néerlandaises de phonétique expérimentale VIII-IX, 1933, 135-144. 
Године су, међутим, прошле, и данас знамо да је Јакобсонов реферат био не само једна од најзначајнијих ствари које су се у проучавању српскохрватског стиха у нашем стољећу догодиле него и један од најважнијих, можда најпрецизнији, потпун приказ фонолошког схваћања стиха. Његов је утјецај на проучавању српскохрватског стиха био огроман. У току минулих четрдесет година неки од најважнијих радова у овој области непосредно се надовезују на Јакобсонов опис, а мало које важно проучавање могло је да га мимоиђе.

Могло би зато бити корисно - и то је оно што бих у овом малом огледу из историје филологије, у пет кратких одељака, желио да учиним - да се нешто пажљивије испитају методолошке претпоставке и консеквенције Јакобсоновог описа, те извори, садржај и природа његовог поступка. Како је предмет овог испитивања Јакобсонов текст, а не српскохрватски епски десетерац, неће се овдје посебно образлагати и доказивати судови о исправности или неисправности овог или оног елемента описа. О једноме и другом много се расправљало у науци, писао сам и са̂м о томе образложено у другој прилици ${ }^{2}$, па ћу то образложење, наводећи поједине судове ради илустрације, овдје подразумијевати.

И још нешто. Постоје извјесне предности и слабости које су подједнако карактеристичне за све значајне оријентације у проучавању стиха у првој половини нашег вијека. На свим странама, на примјер, као методолошки постулат се почетком нашег вијека појављује и затим врло плодним показује правило да се у анализи разликују, увијек узимају у обзир и у међуодносу проучавају два плана или два аспекта стиховнога; обично се називају метром и ритмом, Јакобсонов опис говори о њима као идеалној схеми и поједином стиху, а Јакобсон са̂м касније и другачије (нпр. verse design i verse instance). Или, ни једна од значајних оријентација у проучавању стиха у првој половини нашег вијека - не само она којој припада Јакобсонов опис - није умјела адекватно одговорити на питање о односу стиха и смисла, ни у методолошки најелементарнијој његовој формулацији, на питање наиме: шта уопће резултати метричке анализе значе за неку другу, потпунију, критичку или теоријску анализу истог текста ${ }^{3}$. Тај најопћенитији оквир Јакобсоновог описа може, међутим, и да се занемари у овом малом посебном испитивању у историји филоло-

2 „Поредбено проучавање српскохрватског епског десетерца и спорна питања његовог описа", Зборник МС за књижевност и језик XVII, 1969, 173-203.

3 Потпуније о томе пишем у тексту „The Metametrical Function of Verse Forms”, Teorie verše - Theory of Verse - Теория стиха II, Брно 1968, 15-22. 
гије, којему специфичне особине Јакобсоновог описа морају да остану у средишту пажње.

1. Учење прашке школе омогућило је да Јакобсонов опис буде изванредно концизна а исцрпна и увјерљива критика акустичке метрике, која је управо у то вријеме, користећи се свим знањем и умјећем експерименталне фонетике, довела проучавање стиха у потпун ћорсокак. Двапут у свом опису узгред Јакобсен, додуше, помирљиво напомиње да би се са фонетског становишта могло евентуално оцјењивати рецитовање стихова, што се може данас чинити врло спорним (улога фонетског становишта у теорији стиха, колико се разликује од фонолошког, не би се, мислим, могла корисно замислити тако да му се одреди посебна област проучавања). Али се и данас, опћенито говорећи, може сматрати исправним основни ток Јакобсонове критике, његов изнад свега закључак да фонемске опозиције, а не сва разноликост гласовно-физиолошке или акустичке реализације, чине основу стиха. У духу схваћања прашке школе у Јакобсоновом су опису прихваћене и неке идеје и поступци настали у проучавању стиха раније, у руској књижевности друге деценије нашег вијека (код А. Белог, В. А. Чудовског и других), а развијене у радовима руских формалиста и њима сродних истраживача књижевности (прије свега Томашевског и Жирмунског). Нарочито је значајна међу тим идејама идеја ритмичког фразирања, ритмичке улоге границе међу акценатским цјелинама, која је омогућила и ново, адекватније одређење цезуре. Нарочито је значајан поступак статистички, који је омогућио опис стиха у терминима метричких константи и ритмичких тенденција, дакле адекватно опћој идеји о два плана стиховнога. Ове и из њих изведене идеје и поступци и данас су употребљива и важна оруђа проучавања стиха. Кад им и осјећамо недостатке, немамо за њих праве замјене. Ни развијени математички поступци анализе стиха, какви постоје у наше вријеме, не могу у опису стиха сасвим замијенити једноставну статистичку технику коју је пре шездесетак година замислио Бели. Ни за очигледне недостатке те технике немамо ни данас правог лијека. Иако, на примјер, покушаји да се замисле пробабилистички модели стиха јесу неки корак у том правцу, ни данас се нисмо ријешили основне слабости статистичког описа стиха - најкарактеристичније слабости статистичког описа у свим хуманистичким дисциплинама - да немамо наиме поуздане основе за објективну интерпретацију добивених података, па поуздано и преци-зно утврђене бројчане односе тумачимо од ока.

2. И оно што бисмо данас могли сматрати слабостима прашке школе изразило се у Јакобсоновом опису. При том, разним својим странама, он може бити отворен приговору бар са два супротна становишта, са 
становишта којему се показује, по Мартинеовој ријечи, као тоталитарна слика, умјесто пожељне реалистичке, колико и са становишта које ће његове недостатке видјети као карактеристичне недостатке сваког таксономског описа. Поређењем Јакобсоновог описа са традиционалним описима српскохрватског стиха јасније се показују приговори какви су могући са првог становишта. Фонолошко схваћање стиха помогло је модерној метрици да се сачува странпутице акустичке метрике, и свратило опет пажњу оним особинама стиха којима се занимао и традиционални истраживач. Фонолошки опис најчешће заиста рачуна са истим оним чињеницама стиха са којима је рачунао и традиционални опис - зато је Јакобсон и могао обилно искористити, у разним својим расправама, старије описе српскохрватског стиха, нарочито Маретићев - али им даје ново и потпуније тумачење. Фонолошки опис врсте Јакобсоновог има онда већу експликативну моћ и већу теоријску кохерентност од традиционалног описа, али се у појединим сложенијим или граничним случајевима, зато што тежи примјени исте тоталитарне слике на читаво подручје, показује неадекватнијим грађи од неког реалистичког па чак и од традиционалног описа. У проучавању ритмичког фразирања, на примјер, у свим се описима српскохрватског стиха који су досад настали у традицији Јакобсоновог описа узимало као методолошко правило да је оно што нас занима акценатска цјелина а не ријеч. Практички се то показало најчешће исправним. Постоје међутим случајеви - читави периоди у историји српскохрватске версификације, када се силабички принцип стиха замјењује силабичко-тонским, као доминантним версификационим принципом - у којима се граница између ријечи и њене препозиције у стиху (нпр. у цезури) понаша и другачије него граница међу другим слоговима унутар акценатске цјелине, и другачије него граница међу акценатским цјелинама. Наравно, није тешко одлучити да се наш опис прошири и на границе међу ријечима, али су консеквенције такве одлуке за карактер описа знатно веће него што се на први поглед може учинити. На другој страни, Јакобсонов опис може бити отворен и приговору да није избјегао слабости какве опис, замишљен као емпиријско истраживање које из проучавања одређеног корпуса текстова жели извести опће законитости појаве, вјероватно и не може избјећи. Није то свакако опис епског десетерца у терминима најмањег броја правила којима би се тај стих могао описати, није се у њему испитала могућност да нешто од онога што се таксономском опису као посебна правилност показује буде само аутоматска посљедица некога другог, примарног правила, па ни појединачна понављања и тривијални закључци нису у опису избјегнути. Кад се, на примјер, као константа у фразирању у епском десетерцу наводи правило 
по коме најмање једна од граница сваке акценатске цјелине мора бити пред непарним слогом стиха, дјелимично је ријеч о правилности која је аутоматска посљедица једнога основног правила епског десетерца, а дјелимично о тврдњи која није исправна. Будући наиме да у епском десетерцу није могућа двосложна акценатска цјелина која би заузимала 2. и 3. или 8. и 9. слог, ни четворосложна која би заузимала слог 6. до 9, због зеугме на крају чланка и стиха, своди се Јакобсоново правило на тврдњу да не може бити двосложне акценатске цјелине на 6. и 7. слогу, а та није тачна („Град градила три брата рођена”). Као и у проучавању језика, укратко, тако ће и у проучавању стиха тек наше вријеме моћи да закључи - изричито ће то учинити вјероватно најприје А. Н. Колмогоров, прије десетак година - да не може бити ваљаног описа стиха без хипотезе о његовом генеративном механизму.

3. Јакобсонов опис закључује се излагањем његове данас широко познате хипотезе о индоевропском поријеклу епског десетерца. Тај ће закључак Јакобсон са̂м двадесетак година касније даље развити, и проширити на више других словенских облика стиха, што ће послужити као основа на којој се у наше вријеме успоставио читав један посебан тип генетички оријентиране компаративне метрике. Потпуна процјена читаве оријентације не може се овдје, на жалост, излагати и човјек се зато само са оклијевањем одлучује да укратко изрекне свој сумаран суд: да му се наиме чини методолошки исто онолико занимљивом колико и погрешно усмјереном; развој стиха у историјско доба једноставно не потврђује претпоставку да су се смјене и промјене стиховних облика догађале на начин који би био успоредив са историјским развојем језика, па нема зато никакве основе ни за наду да би било каква реконструкција изворних праоблика могла бити могућа у теорији стиха по прилици реконструкција у историјској лингвистици. Важно је овдје међутим да се запази да је хипотеза о индоевропском поријеклу десетерца формулирана на начин који није био у потпуном складу ни са опћом лингвистичком концепцијом којој је Јакобсон у то вријеме био један од најзначајнијих заступника. Не мора при томе, само за себе, бити најнеобичније што идеја о индоевропском поријеклу, и идеја генетички оријентиране компаративне словенске метрике, добива такав значај баш у програматском тексту угледног прашког структуралисте, мада и то јесте понешто необично (са̂м Јакобсон, уосталом, шест година раније, у предговору чешком издању књиге о чешком стиху, изричито закључује да није могуће компаративно проучавање словенских версификационих система по узору на компаративну граматику словенских језика, и задатак компаративне метрике види, мислим: исправно, у проучавању типолошком). Заиста је 
необично, међутим, што је хипотеза о индоевропском поријеклу десетерца заснована као доказивање о развоју једног појединачног облика, на основи ограниченог броја изолирано узетих појединачних ознака, тако да би својим поступком могла готово да послужи као школски примјер дијахронијског проучавања какво су прашки фонолози сматрали непожељним.

4. Има један закључак у Јакобсоновом опису који је у једној само реченици изречен, па зато обично промакне читаоцу, а врло је значајан због тога што много говори и о природи овог описа, и о његовим претпоставкама, а имао је значајне посљедице и за касније проучавање српскохрватског стиха и стиха уопће. То је закључак по коме је неодржива подјела на стихове квантитативне, силабичке и акценатске. Закључак не слиједи сасвим природно из онога из чега га Јакобсон изводи: из исправног запажања да приликом проучавања стиха треба узимати у обзир не само метричке константе него и ритмичке тенденције, не може наравно слиједити закључак да је неодржива подјела у терминима метричких константи. Напротив, управо разликовање метричких константи и ритмичких тенденција омогућује нам да схватимо хијерархију стиховних особина и да поједине особине тумачимо према њиховом хијерархијском рангу, па да онда јасно и разликујемо, на примјер, стих силабички од стиха акценатског, а да нас при том не збуњује околност што и у стиху силабичком распоред нагласака може имати неку ритмичку функцију. Закључак да је неодржива подјела стихова по версификационим системима није, укратко, могао исправно бити изведен из запажања о важности и ритмичких тенденција за разумијевање стиха. Изведен је он у ствари из једне претпоставке која се у овом контексту није непосредно спомињала али је значајно утјецала на сва Јакобсонова проучавања и теоријска разматрања о стиху. Претпоставка је да је стих одлучно, битно одређен језиком у коме је настао; из ње се природно изводи закључак да је неодржива подјела на версификационе системе, зато што не може бити различитих версификационих система у једном језику, а сваки језик представља и на плану стиха размјерно самосталан систем; на тој је претпоставци онда саздан методолошки постулат свих проучавања српскохрватског стиха која су настала у традицији Јакобсоновог описа о јединственим принципима читаве, и народне и умјетничке, српскохрватске версификације. Претпоставка да је стих као стих битно одређен језиком у коме је настао није, мислим, исправна, али за ово испитивање није важно да се то утврди. Важно је да се запази да та претпоставка није - по својој природи не може бити - научно лингвистичко увјерење, да се она ни из којег лингвистичког схваћања језика неопходно не изводи нити се заправо у 
оквирима лингвистичке теорије било као исправна било као неисправна икако може доказати. Важно је такође да се запази да је, за вољу овог нелингвистичког увјерења, Јакобсонов опис пропустио да на расправу о проблему версификационих система пренесе оно баш за ту сврху плодно опће методолошко искуство што га је управо прашка школа стекла проучавајући у хијерархијском односу елементе језичког система.

5. Како сам показао у другој прилици, Јакобсоново проучавање српскохрватског епског десетерца могло је да упозори на неке особине тога стиха које су промакле другим проучавањима зато што је било основано на опису једне или двије пјесме једног пјевача, па се у њему сачувало оно што се у проучавању већег или разноликијег корпуса губило, због разлика које постоје међу пјесмама разних пјевача у ритмичкој организацији стиха. Јакобсон је, међутим, вјеровао да проучавајући стих једне или двију пјесама може описати епски десетерац као врсту стиха, па је свој опис као такав у даљем закључивању и употребљавао. Више недостатака Јакобсоновог описа епског десетерца, и његовог даљег закључивања о њему (нпр. закључак о старини квантитативне клаузуле), настали су проучавањем које је битно било одређено споменутим вјеровањем. Вјеровање само могло је бити изведено из претпоставке да се на темељу сваког произвољно изабраног узорка стихова мора доћи до истог једног описа структуре стиха, као што се адекватним лингвистичким проучавањем од свих произвољно одабраних узорака неког језика мора доћи до исте једне граматике тога језика. Могло је оно такође бити изведено из претпоставке - из увјерења које се и излаже у познатој програматској студији Јакобсона и Богатирјова - о монолитности усмене пјесничке традиције. Није за ово испитивање важно да се докаже да се претпоставка, ма која од њих била одлучна, није показала исправном. Али је важно да се запази да ни овај пут ни једна од тих претпоставки није - зато што по својој природи не може бити - научно лингвистичко увјерење.

Послије свега, опћа карактеризација Јакобсоновог описа, као свједочанства о једном значајном тренутку у историји филологије у нашем стољећу, може се и укратко изрећи. Како због хетерогености лингвистичког поступка, тако и због мјере у којој је одређен нелингвистичким претпоставкама, није тај опис вјероватно исправно сматрати лингвистичком расправом. Он јест, међутим, врло очигледно расправа једног лингвисте. Настао на почетку великог времена експанзије лингвистике на подручје сусједних наука, вођен и настојањем да се легитимност експанзије потврди, омогућује извођење неких и данас корисних опћих поука о међуодносу лингвистике и теорије стиха. Помоћ се лингвисте теорији стиха показала у нашем случају најдрагоцјенијом, најприје, као 
помоћ доброг лингвисте против мијешања лошег лингвисте, али затим свакако и као помоћ лингвисте у потпунијем разумијевању па зато и прецизнијем одређивању оних већ постојећих појмова и поступака теорије стиха који могу да се виде и тумаче и са становишта науке о језику. При том, однос лингвистике и теорије стиха показује се као однос двију посебних дисциплина; за њихов међуоднос карактеристична је појава коју сам у другој прилици назвао интердисциплинарном рефракцијом, што, поред осталога, значи да се чисте, тоталитарне лингвистичке позиције, које у лингвистици самој имају вјероватно највећу методолошку вриједност, не показују неопходно као најплодније са становишта теорије стиха. Непосредно преношење лингвистичке методологије на подручје проучавања стиха чини се бременито опасностима. Извјесне стварне и многе површне аналогије међу студијским ситуацијама лако наводе на некритичност која дозвољава да се легитимни поступци лингвистичке анализе примењују на предмет којем нису адекватни, а постојање битних разлика међу студијским ситуацијама, основаних највише на околности да стихом одлучно управљају нејезичке литерарне конвенције, потиче да се битне претпоставке изворног поступка занемаре а да се ток властитог проучавања у великој мјери пореди неизреченим и неиспитаним нелингвистичким претпоставкама.

Што Јакобсонов опис српскохрватског епског десетерца није постао жртвом свим замкама које је његова усмјереност имплицирала, што се у историји филологије у нашем стољећу не појављује само као занимљив методолошки tour de force него и као значајно проучавање које је велик дио своје вриједности сачувало до данас, треба да захвалимо околности да се у личности његовог ауторитета врстан лингвиста срео са сензибилним и ученим читаоцем и истраживачем поезије.

Sv.[etozar] Petrović

JAKOBSON'S DESCRIPTION OF THE SERBO-CROATIEN EPIC DECASYLLABLE

Summary

The now classical description of the Serbo-Croatien epic decasyllable, presented by R. Jakobson more than forty years ago, is understood here as a notable document of an important moment in the history of the modern studies in versification, and is examined with a view to the methodology it employs or implies. Selected significant aspects of the Jakobson's description are classified, and analyzed, 
as those which (1) may still be, though with some reservations, considered valid general assumptions or acceptable components of a description of verse, and, at the same time, were either made possible by, or easily adapted to, the linguistic theory of the Prague school; (2) are to be related to the linguistic theory of the Prague school, and, questionable as they are in themselves, seem to be open to the same kind of objections this linguistic theory itself, both as a "totalitarian picture" and as a taxonomic description of linguistic phenomena, is subjected to today; finally, questionable as they are in themselves, as assumptions or statements about versification or poetry, either seem to be also questionable from the point of view of the Prague school's linguistic theory ( 3 and in a special sense 4$)$, or are unrelated to any linguistic theory and are based on some non-linguistic belief ( 4 and particularly 5). In conclusion, Jakobson's description is found to be quite obviosly a study by a linguist, but not a study in linguistics; the qualities by which it still is an important study are attributed to the fact that its author was not only an able linguist but also a knowledgeable reader of poetry. The results of the analysis are ultimately the basis for some general remarks on the use of linguistics in the study of versification. 